WORKING PAPER NO. 7

Oct 1995

\title{
Who Counts Most in Sustainable Forest Management?
}

\author{
Carol J. Pierce Colfer
}

\section{Summary}

This paper proposes a method for identifying and defining the most significant actors in sustainable forest management. A rationale for the importance of differentiating among various forest stakeholders is first provided. Significant stakeholders identified in forest management units in Kalimantan, Côte d'Ivoire, and the USA. are described. These descriptions are followed by a discussion of six important dimensions along which groups of people vary in their relations with the forest (proximity, pre-existing rights, dependency, indigenous knowledge, culture/forest integration, and power deficits). Finally, a simple scoring technique is proposed and demonstrated for the three contexts described earlier.

\section{CENTER FOR INTERNATIONAL FORESTRY RESEARCH}

office address: Jalan CIFOR, Situ Gede, Sindangbarang, Bogor 16680, Indonesia mailing address: P.O. Box 6596 JKPWB, Jakarta 10065, Indonesia tel.: +62 (251) 622622 fax: $+62(251) 622100$

email: cifor@egnet.com

$W W W:$ http://www.cgiar.org/cifor 


\section{The CGIAR System}

The Consultative Group on International Agricultural Research (CGIAR) is an informal association of 41 public and private sector donors that supports a network of sixteen international agricultural research institutes, CIFOR being the newest of these. The Group was established in 1971. The CGIAR Centers are part of a global agricultural research system which endeavour to apply international scientific capacity to solution of the problems of the world's disadvantaged people.

\section{CIFOR}

CIFOR was established under the CGIAR system in response to global concerns about the social, environmental and economic consequences of loss and degradation of forests. It operates through a series of highly decentralised partnerships with key institutions and/or individuals throughout the developing and industrialised worlds. The nature and duration of these partnerships are determined by the specific research problems being addressed. This research agenda is under constant review and is subject to change as the partners recognise new opportunities and problems. 
CENTER FOR INTERNATIONAL FORESTRY RESEARCH

office address: Jalan CIFOR, Situ Gede, Sindangbarang, Bogor 16680, Indonesia mailing address: P.O. Box 6596 JKPWB, Jakarta 10065, Indonesia

tel.: +62 (251) 622622 fax: $+62(251) 622100$

email: cifor@cgnet.com

$W W W:$ http://www.cgiar.org/cifor 


\title{
Who Counts Most in Sustainable Forest Management?
}

\author{
Carol J. Pierce Colfer
}

\begin{abstract}
Summary
This paper proposes a method for identifying and defining the most significant actors in sustainable forest management. A rationale for the importance of differentiating among various forest stakeholders is first provided. Significant stakeholders identified in forest management units in Kalimantan, Côte d'Ivoire, and the USA. are described. These descriptions are followed by a discussion of six important dimensions along which groups of people vary in their relations with the forest (proximity, pre-existing rights, dependency, indigenous knowledge, culture/forest integration, and power deficits). Finally, a simple scoring technique is proposed and demonstrated for the three contexts described earlier.
\end{abstract}

\section{Why Differentiate Among People?}

A global interest has burgeoned recently in the concept of sustainable forest management. Part of this interest has been focused on identifying principles, criteria and indicators on the basis of which sustainable forest management can be judged. The Center for International Forestry Research (CIFOR) is evaluating criteria and indicators selected from five leading certification systems. ${ }^{1}$ The evaluation process includes field tests in four locations (Germany, Indonesia, Côte d'Ivoire, and Brazil). Our focus here is on sustainability at the level of the forest management unit.

In the process of developing a conceptual framework with which to cope with the many social criteria and indicators in the five systems (Colfer with Prabhu and Wollenberg 1995), one major shortcoming quickly emerged. There are many people with an interest, or "stake," in the forests, herein called stakeholders. ${ }^{2}$ The various stakeholders have different rights and responsibilities, which can be placed along a continuum of relevance for day to day forest management. To date, although there is agreement that different stakeholders should have different roles in sustainable forest management, there has been no commonly accepted mechanism for differentiating among these groups.

The sets of criteria and indicators, or guidelines, currently being tested at CIFOR specify actions in relation to different groups of people who have impacts on, and are affected by, the forest. Most guidelines require, for instance, that people's tenure rights3 be respected. Various rights of "local," "traditional," "indigenous," "tribal," "poor," "vulnerable" people, "workers," "settlers," and "communities" are addressed in different sets of guidelines. To test the applicability of these guidelines properly we need a clearer way of identifying the relevant actors (who ought to have which rights and benefits and who has what duties and responsibilities?). This paper suggests factors which should be considered in defining the most critically relevant population(s) for attention in managing a forest unit sustainably, and proposes a mechanism for identifying the comparative pertinence of different categories of people in a particular forest. In so doing, it also allows us to define what are often called "forestdependent people."

1 The sets of criteria and indicators which were tested include Lembaga Ekolabel Indonesia (LEI), the British Soil Association's Woodmark, Rainforest Alliance's Smart Wood (USA), the German Tropenwald and a set from the Dutch Working Group of Experts on Sustainable Forest Management.

2 This use, though current in the sustainable forest management literature, is inconsistent with the dictionary definition: "a person entrusted with the custody of property or money that is the subject of litigation or of contention between rival claimants in which the holder claims no right or property interest." [emphasis added] (Webster's Third New International Dictionary 1993). Behan's (1988) use of the term "constituents" is similar to what we mean by "stakeholders."

3 Globally there is a diverse assortment of different (and legitimate) systems of land tenure and usufruct. I suggest that rather than any particular kind of land tenure or usufruct, the important issue for sustainable forest management is - perceived security of intergenerational access to local resources. 
Progress on this task will be useful both practically and theoretically. A simple way to identify who counts most at the level of the forest management unit will be of great use to local managers as they try to manage their forests in a benign fashion. Clarification of the factors that influence people's relations with the forest - also necessary in determining "who counts" - will contribute to our more general understanding of peopleforest interactions.

All relevant stakeholders, by our own definition, have an interest in the forest. But there are both ethical and pragmatic reasons for attending more closely to some stakeholders than to others. From the ethical perspective, there is a growing recognition that many people living in forests have not been treated "fairly," that their resources have been usurped by more powerful individuals or organisations and that their well being has been adversely affected in a variety of ways (cf. Charter of the Indigenous Tribal Peoples of the Tropical Forests 1992; World Bank 1991; Colchester 1993; and numerous case studies such as those reported in Barber et al., 1994; or Richards 1993).

From the pragmatic point of view, some people have greater likelihood of directly affecting the forest than others. These people I call 'forest actors,' to emphasise their capacity to act on the forest, besides receiving, or failing to receive, benefits from it (see Vayda et al., 1980 for a more complete exposition of this perspective). Whereas the term "forest-dependent people" emphasises what people receive from the forest, "forest actor" emphasises their rights, responsibilities, and potential actions in relation to it. Both the capacity for action and dependency are important elements in the people-forest relationship as it relates to sustainability.

I developed the approach described here while testing criteria and indicators in the company of two inter-disciplinary, five-member teams of experts, on month-long field visits. Field visits were made to P.T. Kiani Lestari Timber Concession which straddles the Telen River in East Kalimantan, Indonesia and to the
Bossematié Forest Reserve near Abengourou in eastern Côte d'Ivoire. I supplement this experience with observations from the Olympic National Forest on the Olympic Peninsula in the State of Washington (USA).

In subsequent sections, I provide a general, descriptive sketch of each of the three settings, to give some idea of land use, population, local issues and trends, followed by thumbnail sketches of the stakeholders. I first describe the setting and stakeholders identified in East Kalimantan, Indonesia (see Tables 1-3, for additional stakeholder traits). Then I present a view of the stakeholders in Côte d'Ivoire's forests, with which I am much less familiar. ${ }^{4}$ My third example is from an American forest. The attempt to apply the approach in the American setting has served as a preliminary test of its wider applicability. 5

In Section III, I propose and discuss six dimensions (reflecting ways in which people are linked to forests) which, I believe, facilitate placement of the stakeholders along a continuum of relevance for day to day management of forests. Finally, in Section IV, I suggest a simple, straightforward technique for identifying those stakeholders who are most important ethically and pragmatically in sustainable forest management. ${ }^{6}$

\section{The Stakeholders}

To date, our method for identifying stakeholders has been qualitative - the best judgement of "experts."7 In all three locations, we identified national citizens, consumers, forest officials, small scale entrepreneurs and forest workers - with various sets of characteristics - as stakeholders. Only consumers were sufficiently comparable in terms of their relations to the forest to be treated here "generically."8

Consumers - These people make use of forest products. Virtually all are concerned about maintaining affordable access to such products, and some are concerned about the sustainability of forest management.

4 I have drawn on the long-term, West African experience of Ahui Anvo, Heleen van Haaften, Charles Huttel, Jean Claude Koffi Konan, Patrice Mengin-Lecreulx, and Anatole N'Guessan, for the Côte d'Ivoire analysis, and I am grateful for their considerable help.

5 A fourth test of this method will be conducted in Brazil in October-November 1995.

6 I emphasise that what we are doing is still in process. We are trying to gain a fuller understanding of both the social aspects of sustainability at the management unit level, and ways to evaluate them quickly, simply, and accurately. Input and critiques from readers are most welcome.

7 Once the relevant stakeholders have been broadly identified, additional fine-tuning will be necessary. Nurse et al. (1995) used participatory mapping techniques in Cameroon, to identify various categories of users with different rights and responsibilities.

8 This generic quality may, of course, simply reflect the focus that has so far been directed toward people closer to the forest management unit. 
Each location had both an additional set of stakeholders and different features of the shared stakeholders.

\section{A. Stakeholders Connected with the P.T. Kiani Lestari Timber Concession in East Kalimantan, Indonesia (Borneo) 9}

The Indonesian Ministry of Forestry manages all forested land on behalf of the State. In areas of Kalimantan classified as production forest, it awards timber concessions to private and para-statal businesses. These concession holders then agree to manage the forest concession according to Indonesian law and forest policy. Scattered throughout P.T. Kiani Lestari's 340,000 ha of lowland dipterocarp forest concession are villages of Dayaks (Borneo's largely Christian and animist, indigenous people) and Kutai (a local Muslim, Melayu ethnic group), each with a traditional system of land tenure, forest management and use rights. ${ }^{10}$ Most of these people had practised a sustainable form of swidden cultivation under conditions of low population density (prior to the last decade). Their agricultural activities are supplemented by forest use (hunting, fishing, gathering of forest products) and male circular migration for wage labour. The people identified as living in the concession in 1989 numbered 20,308 (FAO 1989), a density of roughly 60 people $/ \mathrm{km}^{2}-$ much higher than either the traditional context or the provincial average of $7.7 / \mathrm{km}^{2}$ (Beukeboom 1989).

Ten thousand hectares of this concession have been developed as a transmigration location for governmentsponsored settlers from Java and other densely populated Indonesian islands (Sakuntaladewi and Amblani 1989). One hundred and eight thousand $(108,000)$ hectares in this concession have been categorised as conversion forest, most of which is going into "industrial timber estates" (HTI, or Hutan Tanaman Industri) with Acacia mangium as the dominant species. There are four communities of HTI transmigrants in the concession who began coming, mainly from Java, in 1990 to supply the labour needed for developing the plantation areas.
The changes that are occurring include a drastic reduction in the area of natural forest (with probable accompanying reduction in biodiversity), rapidly increasing population from in-migration (primarily government-planned), significant reduction in the cultural integrity of East Kalimantan's original inhabitants, and increasing agricultural problems due to environmental degradation.

Dayaks - These people (including a number of subgroups, such as Kenyah, Kayan, Bahau) practise a riverine lifestyle in the forests. They tend to have occupied a definable area, though not necessarily that particular village site, for decades and sometimes centuries. Most have less power, money and formal education than members of the dominant society. ${ }^{11}$ Their systems include useful knowledge about their environment and indigenous forest management practices which are often under-valued and misunderstood by outsiders (see e.g., Brookfield and Padoch 1994; Colfer with Peluso and Chin, in press). They also normally have some, varying, commitment to maintaining their forested environment and way of life. They are the primary "losers" within the current approach to forest management.

Kutai - These long-resident, local people of Melayu, Muslim heritage and culture live in riverine communities, interspersed with the Dayaks. Their agroforestry system is similar to that of the Dayaks, with a major difference being the Kutai's somewhat more commercial orientation and a greater level of acceptance by members of the dominant society (due to shared religion and greater historical prominence the Kutai Sultanate in Tenggarong).

Transmigrants - They have moved to the forest from more densely populated contexts (e.g., Java, Timor, Flores) characterised by intensive agriculture in most cases. They are poor, with few economic alternatives (cf. Vayda and Sahur 1988 on Bugis pepper farmers; Colfer 1991 or Davis 1988 on transmigrants). They typically come as families, intending to practise settled agriculture, often under

9 I conducted one year of ethnographic research in Long Segar, a village in Kiani Lestari's (then Georgia Pacific's) concession, in 1979-80, as part of the Man and the Biosphere project, "Interactions Between People and Forests in East Kalimantan.” I made additional, shorter research visits in 1981, 1983, 1991, and 1995.

10 Land ownership in Indonesia is a sticky issue. The Ministry of Forestry has identified "forest lands" all over the country which are claimed for State ownership (Basic Forestry Law 1967). The Ministry of Agriculture has a body of law pertaining to "adat" (or customary) rights of local people and the State's respect for those rights (Agraria 1976). These two bodies of law are in direct conflict. Local land conflicts are resolved on a case by case basis, often to the disadvantage of those residing in the forests.

11 By the "dominant society," I refer to Muslims from Java who represent a majority in the Indonesian population and in the Government and whose interests dominate national policy. 
national government sponsorship. Their affiliation with the Transmigration programme and (often) shared ethnicity with government officials also give them more influence than the original inhabitants of the area. Recent transmigrants are unfamiliar with ways to thrive in and sustain forested environments, tending more toward agricultural lifestyles. Some have come to the area simply to exploit it and leave; others intend to stay. The conservation views of transmigrants are likely to focus on "soil management" more than "forest management." Over time they may take on or adapt some of the knowledge and practices of forest people (Fulcher 1982).

Forest workers - Timber companies hire labourers. Kiani Lestari reported 543 workers in 1989 (FAO 1989). P.T. Alas Helau (a related firm, working in the same concession area) had 725 workers in 1995, with the most common ethnic groups being Javanese (34\%), Kutai (23\%), Timorese (13\%), and Bugis $(11 \%)$. The men (fewer than $5 \%$ of Alas Helau's workers were women) tend to work under hazardous conditions, often with little knowledge of careful logging practices - either for their own safety or environmental protection. Most women work in the informal sector (including prostitution, with all the physical and mental health hazards that accompany that occupation). ${ }^{12}$ Many forest workers are far from their families and other traditional sources of social control or protection, though some may settle after logging operations end.

Small-scale entrepreneurs - They may be in business or government. They have information and capital which allows them to participate in the marketing and processing of forest products. They also may engage in land speculation, hiring others to log (usually illegally) ${ }^{13}$ and/or to clear forest areas which they later claim.

Company officials - These are comparatively educated, upper echelon employees of enterprises which harvest forest products. They typically come to the forest from some other, more urban, area with little knowledge of local conditions, either human or environmental. They represent a national presence in remote, forested areas, and may have significant power over the lives of forest-dwelling people.

Forestry officials - These are employees of the Indonesian Ministry of Forestry. They are technically responsible for forest management, yet do not have the resources (human or financial) to manage effectively. Their official mandate includes protecting the forest and, to a lesser extent, contributing to the well-being of the people.

Environmentalists - These are urban-based people, concerned about Indonesia's forests. They exert pressure on the government and on companies to enhance the sustainability of their timber operations.

National citizens - These people have a stake in the forest, as beneficiaries of forest-derived revenues, passed on, to some extent, in the form of development programmes.

\section{B. Stakeholders in Côte d'Ivoire}

Bossematié Forest, ${ }^{14}$ near Abengourou in eastern Côte d'Ivoire, and Haut Sassandra to the west, are "forest reserves," meaning that they are under the jurisdiction of SODEFOR (a governmental management entity) and legally unavailable for agricultural use by local people (SODEFOR 1994a, b). Governmental perceptions of ownership (extant since French jurisdiction) conflict with indigenous views on tenure and usufruct. The forest is severely degraded, and efforts are under way to rehabilitate it through planting of various commercial tree species. Logging and agriculture are no longer permitted in Bossematié. Riezebos et al. (1994) describe a situation of conflict over land among indigenous inhabitants and newcomers to the north and west of Haut Sassandra.

12 Enloe's (1989) historical discussion of plantations in colonial Indonesia is relevant here:

"Prostitution became the norm on many plantations by design, not simply chance. There are records revealing that managers debated the advantages and disadvantages of prostitution for their company.... [T] he prevailing view was that it would be too difficult to recruit male workers for plantation work if they were not provided with female sexual services. Furthermore, in the eyes of many plantation managers, prostitution was a lesser evil than homosexual relations between male workers deprived of female companionship. Finally, devoting a sizeable portion of their wages to prostitution left many male workers further in debt and thus made it harder for them to abandon estate work when their current contracts expired."

The same acceptance of the necessity for prostitution was expressed by company personnel in Kalimantan, perhaps for the same reasons.

13 I know of one case in West Kalimantan where indigenous Iban leaders are partners in a timber company venture, in which case their logging is legal.

14 I emphasise Bossematié here because that is the area I was able to visit. 
Ehui and Hertel (1989) report Côte d'Ivoire as having the highest deforestation rate in the world $(300,000$ ha or $6.5 \%$ per year, from an original 16 million ha of tropical rain forest). They also report a 4.7 million ha "Permanent Forestry Domain" and a 731,750 ha "Rural Forestry Domain" in 1978, which had significantly declined by 1987.

In Côte d'Ivoire, forestry problems are related to agricultural problems. In a 1986 study, Wiersum noted a general decrease in the stability and sustainability of indigenous shifting cultivation systems because of "the availability of less land per cultivator, lower fallow/cultivation ratios, and often also decreased crop and tree diversity." He also noted that the change from shifting cultivation to permanent cash-crop cultivation had not resulted in stabilisation of land use, but rather in further intrusions of agricultural land into the forest. Van den Breemer (1989) reports the existence, among the Aouan (near Bossematié), of "a system of conceptions and rules which, at an unconscious level, directs people towards preservation of the ecological balance." But he also notes internal processes of social change with "devastating influence on the environment." Van Reuler et al., (1994) document similar trends near Haut Sassandra.

In Bossematié, a German-Ivoirean project is working with the communities surrounding the forest trying to develop alternatives to their traditional agroforestry system of food crops supplemented with hunting and planting of cacao and coffee (Aha Badou et al.,1992; SODEFOR 1994a). This project is making significant efforts to encourage the participation of local communities in their planning and activities (in contrast to the national historical bias against farmer participation, e.g., Miracle 1970).

There is considerable local population pressure from in-migration (both Ivoirean and from adjacent countries) and from natural increase. Riezebos et al. (1994) note that in the south-western region of the country (where Haut Sassandra is located), in-migration from Mali, Burkina Faso, Liberia and other parts of Côte d'Ivoire averaged $10 \%$ per year between 1970 and 1990. The indigenous population now comprises roughly $10-20 \%$ of the total. The number of inhabitants $/ \mathrm{km}^{2}$ increased from $8 / \mathrm{km}^{2}$ in 1971 to $135 / \mathrm{km}^{2}$ in 1991 in some areas near Tai National Park.

SODEFOR (1994a) estimates the 1991 ethnic composition of the Bossematié population as $62 \%$ Agni (indigenous), $15 \%$ in-migrants from other Ivoirean areas (Baoule), 21\% from Burkina Faso and 2\% from Mali. Between 1975 and 1988, SODEFOR found the average rate of population increase in the area to be $4.7 \%$ (with increases in some areas as high as $11.2 \%$ ). Population density ranges between 20 and
50 persons $/ \mathrm{km}^{2}$. Planting of food and tree crops in the Bossematié Forest (both legal and illegal) is coming under some control by SODEFOR. Combining local poverty, uncontrolled in-migration and natural population increase with attempts to rehabilitate and protect forest reserves provides daunting management problems (cf. van den Breemer 1992).

Many of the following stakeholder categories are comparable to the Indonesian case.

Agni (Autochtones) - the ethnic group residing in and near the forest. Our sources suggest that not even these people have long-standing rights in Bossematié Forest (Aha Badou et al., 1992). The matrilineal Agni do however have a tradition which includes agroforestry uses of the forest (see van den Breemer 1992, on the nearby and similar Aouan system). They also periodically and traditionally incorporate members of other ethnic groups into their system. This system, besides providing the Agni with labour, serves a broader "social security" function in the region, providing a subsistence option for the hungry.

Forest workers - These include loggers who work for contractors (tacherons), under big companies/ SODEFOR and service professions (including prostitution in an area where HIV positives comprise $15 \%$ of the population, van Haaften 1995).

Allochtones - Ivoireans from areas residing in or near the forest. These people move to the forests in times of economic or environmental stress in their home areas, to work for indigenous people (in/near forests). Some come from other previously forested areas; others from the savanna and desert regions to the North - thus they have varying levels of indigenous knowledge of forest ecosystems and management.

Allogens - foreigners, in most cases refugees (political and economic) in or near forests. Their role in sustainable forest management is similar to that of the Ivoireans from other areas except that they have fewer rights. De Bruijn and van Dijk (1995) discuss the difficult subsistence problems in Mali which make this kind of social security system so important.

Tacherons - Local contractors who run small-scale logging operations or do other forestry-related work for larger companies.

Forestry officials - People who work for the government (Dept. of Forestry, SODEFOR, etc.) who may also be physically distant from the forest.

[National Citizens - The role of these people was not investigated in Côte d'Ivoire, but that they have 
some, perhaps increasing, stake in the nation's Forest Reserves is highly probable.]

Company officials - People who work for large logging companies, normally at some distance from the forest, but with considerable voice in its management.

[Environmentalists - Only a few environmentalists were in evidence in Côte d'Ivoire, but their relevance may be growing, supported by increasing international concern about Côte d'Ivoire's forests.]

\section{Stakeholders in the Olympic National Forest (Bushler Bay, Washington, USA) 15}

Bushler Bay, Washington, is a community on the Olympic Peninsula of about 2,000 people. It houses the headquarters for the US Forest Service office which manages the adjacent Olympic National Forest, a temperate rain forest dominated by Douglas Fir and Hemlock (see Kirk with Franklin 1992, for an ecological description). The community is sharply divided between "locals" (loggers, fisherfolk, oyster farmers, and business people) and "public employees" (employees of the school, US National Park Service, US Forest Service, Washington State Shellfish Laboratory, and Washington State Fish Hatchery; Colfer with Colfer 1978).

In recent years there has been a sharp increase in conflict in the area due to changing policies and ideas on forest management (Lien 1991). Environmental issues (symbolised by concern about the spotted owl and the marbled murrelet) are juxtaposed against the livelihood and way of life of logging communities in the area (Dietrich 1992; Barber et al. 1994).

By 1995, the US Forest Service had closed the entire Bushler Bay Ranger District of the Olympic National Forest to logging. The number of loggers in the community had dwindled to such a degree that the remaining small-scale entrepreneurs had to find loggers in other communities on the Peninsula. ${ }^{16}$ Log truck drivers complained that they had to drive all over the western half of the State. A thriving logging community in the 1970s, the 1990s characterisation was "a home for welfare recipients and retired folk."

Important differences from the previous two examples include clearly defined land rights and a national ideology in support of community participation in forest management (even if rendered somewhat academic by the distant locus of ultimate decision making). ${ }^{17}$ As in Indonesia and Côte d'Ivoire, however, there is a widespread malaise about the future, from the perspectives of timber production, the environment and society. The following stakeholders play important roles there. ${ }^{18}$

Loggers - This term encompasses both the men engaged in cutting and transporting logs and their families. Indeed, it is a shorthand for a whole way of life in which logging is closely associated with manhood and independence (Colfer 1977). Formal education is not highly valued and "paper pushers" are granted little respect. Logger families are more likely to have long-standing roots in the community, close kin ties with other community members, and to own land (and forest) than are the other stakeholders. They are also likely to make use of the forest as a supplementary food source (hunting, fishing, gathering mushrooms, berries, and other minor forest products).

Small-scale entrepreneurs - These people run the businesses that support the logging industry and often include ex-loggers who have "made good." They may also own small logging companies which bid on logging contracts with private individuals and/or (previously) the US Forest Service.

Environmentalists - In the Bushler Bay context, these people can be described as part of the "back to the Earth" movement. Many are well educated from urban backgrounds seeking a more peaceful life, more closely attuned to nature. They are likely to rely heavily on the forest for food supplements. They are often in open conflict with logger families and the US Forest Service over issues of natural resource management (cf. Lien 1991). Distant environmentalists also have an impact in Bushler Bay, through a variety of means (votes, letter-writing, demonstrations, fund-raising). ${ }^{19}$

15 I did ethnographic research in Bushler Bay, Washington, between 1972 and 1975, with continued involvement in the community until 1980. I made three brief return visits in 1994 and 1995.

16 At the small-scale logging operation I observed in 1995 (on private lands), I interviewed five workers, only one of whom was from Bushler Bay (the boss).

17 See Smith and Steel's (1995) analysis of decision-making, participation, and power in Pacific Northwest Coast resource dependent communities (USA).

18 Dietrich's (1993) book includes chapters on "cutters," "biologists", "truckers," "environmentalists," "foresters," "candidates."

19 Dennis Dykstra (personal communication, July 1995) originally pointed out the importance of distant environmentalists as stakeholders. He argues that although their dependency on the forest is significantly less than that of people living in and around the forest, their impact on management may be greater (see also Smith and Steel 1995). 
Government employees - These people are primarily employees of the US Forest Service and US Park Service. Bushler Bay, Washington, is surrounded by government-managed National Forest and National Park. Public employees with these organisations and their families - who made up about half of the population in the 1970s - tend to come from other areas, often having joined the Forest or Park Service in search of an outdoor lifestyle. They find, instead, that their lives are full of the "paper shuffling" disdained by their neighbours. Most are middle class, upwardly mobile people, who value education, propriety, moderation in all things. They tend to look down on local people as "lower class," uneducated, and promiscuous (Colfer with Colfer 1978; Colfer 1977). Now they also see loggers as responsible for environmental degradation.

Politicians - These people participate in decision making at the state and national levels. They represent one avenue through which their constituencies can make their preferences known. With regard to contexts like Bushler Bay, they are continually bombarded by environmentalists, on the one hand, and the timber industry on the other.

National citizens - These people have an indirect, but real, voice in forest management. People from all over the United States, by voting or by writing letters to their elected representatives (politicians), can influence the management of any given National Forest or National Park.

\section{Human Dimensions pertaining to Sustainable Forest Management}

In order to define which people are most important for sustainable forest management at the management unit level, it has first been necessary to identify the most important elements or dimensions in people-forest interactions. Without being quite clear about how people and forests are (or can be) related, determining those people most relevant for forest management unit attention becomes problematic.

In the following discussion I have tentatively identified six continua or dimensions pertaining to peopleforest interactions, along which stakeholders can be placed. These dimensions, found to be important in selected forests in Indonesia, Côte d'Ivoire, and the United States, pertain to human well-being and to people's potential positive and negative contributions to forest management. They all have both a pragmatic and an ethical aspect. They all need more precise definition.

\section{Proximity to Forest}

By proximity, we mean simply closeness to the forest. We are acknowledging the potential for people living near the forest to have a significant impact on it. The actual physical distance constituting "proximity" will vary from one forest to another, given the differences in accessibility of various locales. Bushler Bay, Washington, is served by an excellent road and ferry system, linking it to the city of Seattle within a couple of hours. On the other hand, the trip from East Kalimantan's small provincial capital of Samarinda to Batu Ampar (the concession's base camp) can take from six hours (reportedly) to two days.

People with easy access to the forest can be beneficially involved in forest management; indeed, we argue elsewhere that they must have that option (Colfer with Prabhu and Wollenberg 1995). People who perceive themselves to be unjustly excluded from nearby forest also have the ability, directly or indirectly, to degrade it. The extensive literature on the negative ecological impact of roads into forest areas (e.g. Mahar 1989, Moran 1981, 1990) reflects another aspect of this dimension.

Behan (1988) provides cogent arguments for management by "constituents" ("the people who know and care about a particular ...forest"), most of whom he sees as clustered in geographic proximity to that forest. But he raises an important issue. There are people who may know and care about a forest who do not live near it. He argues that such people have a right to be involved in forest management, just as we should respect the rights of others not to be involved if they so choose. One possible way to deal with this dilemma is to include emotional, as well as physical, proximity in this dimension. The relative potential impact of physically distant/emotionally close constituents vis-à-vis physically close constituents is a topic for further investigation.

\section{Pre-Existing Rights}

The meaning of this dimension also varies considerably from place to place (see Sayer 1991, for instance; Fortmann and Bruce 1988; or Poffenberger 1990). In many places endangered forests are subject to conflicting land claims, indeed even to conflicting paradigms of what land ownership and use should mean. Sometimes communities that have occupied a given area for decades, centuries or even millennia, have had their traditional rights usurped or severely compromised in recent times (cf. Colchester 1993; Colfer with Dudley 1993).

If there are such people in or near a forest, recognition of their rights is important both ethically and prag- 
matically. Justice requires that people's rights in the forest be acknowledged and respected. From a purely practical point of view, perceived injustice can lead to a variety of ills from disregard of forest policies to increases in conflict, vandalism and violence (cf. Guha 1993, for examples from India; Barber et al. 1994 or Peluso 1992, from Indonesia; Richards 1993, from Amazonia).

\section{Dependency}

In many forested areas there are communities which are dependent on the forest for a range of goods and services (see FAO's Community Forestry project papers on forest dependency; the 1993 compendium by Hladik et al.; Redford and Padoch's 1992 collection). The people may hunt, fish, gather foods, medicines and fibres, or practise agroforestry. It is also common for such people to have few realistic alternatives to their existing way of life $^{20}$ (cf. Peluso 1991, 1993). The needs of people whose livelihoods depend on the forest must be incorporated into sustainable forest management. Ethically, people's access to food is an important consideration. Practically, people whose children are hungry because they are denied access to the forest may not respect forest borders.

\section{Local Knowledge}

People who have lived in forested areas often have unique and useful knowledge, based on their long-term, local experience (see for example, Banuri and Marglin 1993, Clay 1988, Moran 1993; Posey 1992, 1993). Such knowledge may pertain to animals and their behaviour, plants and their management, uses of various products, techniques for processing forest products, etc. Local knowledge is valuable for its own sake, given our comparative ignorance about the ecology of forests (particularly tropical forests). But it can also serve an important function in incorporating local people actively and beneficially in forest management. Recognition of the utility of their knowledge and its use are powerful tools for enhancing communication and cooperation between local people and other forest managers and for empowering local people.

\section{Forest/Culture Integration}

Cultures (or ways of life) tend to be intimately linked to their environments, ${ }^{21}$ and forest communities are no exception to this rule. There may be sacred sites within the forest, symbolic systems which give meaning to life and are intimately tied to people's sense of self, security functions of forest plants during times of scarcity, and myriad other connections.

When we applied our approach to identifying forest actors in the American Olympic National Forest, it became clear that for "environmentalists," forest maintenance is intimately tied to their values and world view (cf. Vail 1993, for a discussion of a similar situation in Maine) - though this world view may have been consciously chosen in a way that is unlikely to occur in the other two contexts we have examined.

Insofar as a people's way of life is integrated with the forest, the continuation of their culture is jeopardised by forest loss. Such destruction of cultures has demoralising, marginalising, and generally destructive impacts on the people so affected (see for instance, van Haaften and Van de Vijver 1995; de Briujn and van Dijk 1995). Practically, this can mean increases in poverty, mental and physical illness, and various social problems. The human repertoire of cultural diversity is also thus impoverished.

\section{Power Deficits}

In many areas, the people who live in or near the forest have comparatively little power, $v i s-\grave{a}$-vis other stakeholders (see Salafsky et al. 1993, for a discussion of this in West Kalimantan; Smith and Steel 1995 in the US Pacific Northwest). ${ }^{22}$ Such power may be based on education, wealth, or locally recognised authority. Where a local power deficit does exist, it may adversely affect the forest, since the people will not have the means with which to protect their resources (cf. Banuri and Marglin 1993; Barber et al. 1994). Both environmental degradation and reduced human welfare may result.

Another element in the power issue pertains to whose knowledge "counts" (Ardener 1975; Colfer 1983; Jordan 1991, in press). Banuri and Marglin (1993b: 43), in

20 In saying this, it is important not to rule out the possibility that the availability of alternatives may change in the future. The important concern here is that those dependent on the forest not be prematurely and forcibly deprived of their subsistence base, that they have a voice in determining the speed and direction of change.

21 Indeed, there is a whole body of theory called "environmental determinism" which argues that cultures are determined by the environmental conditions in which they arise. Harris (1968) presents a more sophisticated approach rooted in these models, which he called "techno-environmental determinism."

22 Dove (1993) has a germane comment: "The problem for the forest peoples is that they inhabit a resource which is coveted by groups that are more powerful than they are (while the problem for the forest is that it is inhabited by peoples who are too weak to insist on its sustainable use). 
discussing India, point out a globally common pattern which in some cases adversely affects sustainable forest management:

"By labeling the tribals backward and ignorant, by decreeing that their practices destroy the forest, the protagonists of the dominant system of knowledge ensure that the voices which could challenge them will not be heard."

This common silencing, or muting, of some people's voices has a number of potentially dangerous effects, such as reducing their ability and willingness to participate in co-operative forest management or reducing formal managers' access to useful knowledge.

\section{Differentiating Forest Actors from Other Stakeholders}

Defining the relative importance of various stakeholders (for use by forest managers) and identifying those people whose dependence on the forest is significant (for use in development and conservation efforts more generally) have already been identified as important tasks. In this section, building on the previous sections, I outline a method - field tested in three contexts - for distinguishing such people. For use as a tool immediately available to certifiers, the method may be adequate as is. However, from a scientific standpoint, it needs additional work. I conclude with a discussion of remaining conceptual and methodological problems.

I have used the six dimensions linking forests and people, outlined immediately above, to define which stakeholders may need special attention at the forest management unit level - both because they may have un- or under-acknowledged rights to forest benefits and because they may have greater potential for direct impacts on the forest (for good or ill).

Tables 1-3 are matrices for each location, wherein the left-hand column lists the stakeholders, and the top row lists the dimensions. In these matrices I have scored the relevant stakeholders on the degree to which each dimension generally applied to them: $1=$ high, $2=$ medium, 3 = low, and "var." = variable. The scoring process involved first making an estimate based on experience, in the cases of the East Kalimantan forest concession and the Olympic National Forest. In Côte d'Ivoire, I based the scores on brief field observations (perhaps comparable to those of a certification team). ${ }^{23}$ These estimates were then discussed with the other team members and revised accordingly. The mean score for each column (excluding "variable" scores) is computed to the right of each table. The stakeholders have been arranged so that the mean scores increase as we move down the columns. A reasonable cut-off point for defining forest actors seems to be a score of $<2$.

Within the context of testing criteria and indicators for sustainable forest management, this method is reasonable. It is quick, easy, and so far has yielded results which seem intuitively to be consistent with the spirit implied in the criteria and indicators tested. However, a number of refinements will be necessary before the method can be widely and confidently applied. These problems fall into three categories:

- Identification and definitions of the six dimensions

- Weighting of the dimensions

- Scoring method and cut-off point

The identification of the six dimensions derived most fundamentally from experience in Indonesian and American rain forests. For this reason, the dimensions need to be evaluated carefully by specialists in other areas. Our experience in Côte d'Ivoire (combined with a literature review) suggests that these dimensions also apply there; but a one-month field trip cannot replace the careful analysis of researchers with long-term experience among the people residing in and near Côte d'Ivoire's forests.

Additional features may need incorporation; certainly the current dimensions need more precise definitions. Indeed, at this stage, the dimensions do not have formal definitions; the ideas are simply described as they pertain to forest stakeholders. In the US case (analysed last), it was necessary to incorporate the presence of sometimes geographically distant stakeholders who have an emotional commitment to the forest. This additional feature, I dealt with by broadening the descriptions of two dimensions: "proximity" and "culture/forest integration." Further alterations of this type may be in order.

The relative weights of these six dimensions present a particularly thorny problem. The method, as used in this paper, assumes equal weights for all six dimensions. This may very well be an unwarranted assumption. Additional research is needed to determine the comparative importance of each dimension. One possibility is that different dimensions will vary in importance with

23 Seymour et al. (1995), for instance describe their (Scientific Certification Systems, SCS) field visits as requiring only $2-12$ days. 
context, so that weighting will have to be determined locally. 24

The final problem so far identified with this method pertains to scoring. For use on a one-month field trip on which numerous other evaluations must be made as is the case with certification teams - the simple 1-3 scoring system makes a lot of sense. As initially conceptualised, the scoring technique was a convenience, designed to help evaluators looking at the sustainability of a particular forest to identify the people requiring particular attention, quickly and easily. However, for wider use, it may be useful to refine the scoring system. ${ }^{25}$ A variety of scales are being considered. Various readers have suggested 1-4, 1-5, 0-5, 110 , and 1-100 scales as more appropriate. Some prefer granting the respondent the option of selecting a midpoint; others would like to preclude this.

Since the dimensions are conceived as continua (ratio scale), there is in fact no real need to use a nominal scale (other than simplicity). One possibility that seems attractive involves allocating 100 points to the entire matrix, and allowing the respondent to allocate them among the cells as they see fit. This simultaneously makes the data more amenable to statistical analysis and provides a built-in solution to the weighting problem mentioned above (Maxwell and Bart 1995). The problem is that it makes the task of filling in the matrix significantly more difficult. It may also imply a precision that does not in fact exist.

Finally, the cut-off point, for forest actors vs. other stakeholders, needs further consideration. Although in the cases examined in this paper, "2" has seemed a quite obvious and consistent differentiating value, this may not always be the case. It may be necessary or desirable to determine a locally preferred value. These are topics worthy of further investigation.

This simple technique was first developed for use in Kalimantan. One of the most interesting findings to date has been its fairly easy applicability in Côte d'Ivoire (a setting with which I was quite unfamiliar). A second surprise was the ease with which the approach could be applied in the North American context. I expect to try the approach again during our Brazil test, making further refinements as needed.

Placing stakeholders in their appropriate places along these six continua, using one method of estimation or another, is - I would argue - useful in determining their likely relevance for sustainable forest management (including both impacts on the forests and on human well-being). In our first three methodological trials, we've found it to be comparatively simple, straightforward and generally applicable. I now look forward to fine-tuning the method for more general use.

24 Seymour et al. (1995) report that one of the first tasks of a Scientific Certification Systems team is to develop "case-specific weights for the several evaluation criteria within each of the three program elements [timber resource sustainability, forest ecosystem maintenance, and financial and socio-economic sustainability]..."

25 The "score" of "variable," for instance, is not legitimate. CIFOR's statistician, P. Venkateswarlu, has suggested that trying to estimate an average score for the varying stakeholders would be acceptable. 


\section{Bibliography}

Agraria. 1976. Undang Undang Pokok Agraria (Undang Undang No. 5, Tahun 1960). Departemen Dalam Negeri, Direktorat Jenderal Agraria, Jakarta. [English translation]

Aha Badou, A., M.K.A. Simon and J.-P. Eschlimann. 1992. Gestion Traditionnelle de la Forêt: Le Cas AgniNdenye. Anthropological Studies Volume I, Rehabilitation of the Bossematié Classified Forest, Abengourou, Côte d'Ivoire.

Ardener, S. (ed.) 1975. Perceiving Women. Malaby Press, London.

Banuri, T. and F.A. Marglin. 1993a. A systems-of-knowledge analysis of deforestation, participation and management. In: T. Banuri and F.A. Marglin (eds.), Who will Save the Forests?: Knowledge, Power and Environmental Destruction. Zed Books, London. pp. 1-23.

Banuri, T. and F.A. Marglin. 1993b. The environmental crisis and the space for alternatives: India, Finland and Maine. In: T. Banuri and F.A. Marglin (eds.), Who will Save the Forests?: Knowledge, Power and Environmental Destruction. Zed Books, London. pp. 24-52.

Barber, C.V., N.C. Johnson and E. Hafild. 1994. Breaking the Logjam: Obstacles to Forest Policy Reform in Indonesia and the United States. World Resources Institute, Washington, D.C.

Basic Rules of Forestry. 1967. Ministry of Forestry, Jakarta.

Behan, R.W. 1988. A plea for constituency-based management. American Forests (July/August): 46-48.

Beukeboom, H. 1989. Provincial Forest Economic Profiles. Ministry of Forestry/FAO, Jakarta.

van den Breemer, J.P.M. 1989. Yam cultivation and socio-ecological ideas in Aouan society, Ivory Coast. Sociologia Ruralis 29(3/4): 265-279.

van den Breemer, J.P.M. 1992. Ideas and usage: environment in Aouan society, Ivory Coast. In E. Croll and D. Parkin (eds.), Bush Base, Forest Farm:Culture, Environment and Development. Routledge, London. pp. 97-109.

Brookfield, H. and C. Padoch. 1994. Appreciating agrodiversity: a look at the dynamism and diversity of indigenous farming practices. Environment 36(5): 6-11 and 37-43.

de Bruijn, M. and H. van Dijk. 1995. Arid Ways: Cultural Understandings of Insecurity in Fulbe Society, Central Mali. Thela Publishers, Amsterdam.

Charter of the Indigenous-Tribal Peoples of the Tropical Forests. 1992. Malaysia, Penang (15 February).

Clay, J.W. 1988. Indigenous People and Tropical Forests. Cultural Survival, Inc., Cambridge, Mass.

Colchester, M. 1993. Forest peoples and sustainability. In: M. Colchester and L. Lohmann (eds.), The Struggle for Land and the Fate of the Forests. World Rainforest Movement/The Ecologist/Zed Books, New York. pp. 61-95.

Colfer, C.J. Pierce. 1977. Women's Communication and Family Planning: The Case of Bushler Bay. East-West Communication Institute, Honolulu (Case Study \#4, reprinted 1978).

Colfer, C.J. Pierce. 1983. On communication among 'unequals'. International Journal of Intercultural Communication 7: 263-283.

Colfer, C.J. Pierce. 1991. Toward Sustainable Agriculture in the Humid Tropics: Building on the TropSoils Experience in Indonesia. TropSoils Technical Bulletin No. 91/02. Raleigh, North Carolina.

Colfer, C.J. Pierce with A. M. Colfer. 1978. Inside Bushler Bay: lifeways in counterpoint. Rural Sociology 42(2): 204-220.

Colfer, C.J. Pierce with R.G. Dudley. 1993. Shifting Cultivators of Indonesia: Marauders or Managers of the Forest? FAO Community Forestry Case Study Series No. 6. FAO, Rome.

Colfer, C.J. Pierce with N. Peluso and Chin See Chung. In press. Beyond Slash and Burn: Lessons from the Kenyah on Management of Borneo's Rain Forests. New York Botanical Garden Press, New York.

Colfer, C.J. Pierce with R. Prabhu and E. Wollenberg. 1995. Principles, criteria and indicators: applying Okham's Razor to the people-forestry link. CIFOR Working Paper No. 8, Bogor.

Davis, G. 1988. The Indonesian transmigrants. In: J. Denslow and C. Padoch (eds.), People of the Tropical Rain Forest. University of California Press, Berkeley. pp. 143-153.

Dietrich, W. 1992. The Final Forest: The Last Great Trees of the Pacific Northwest. Simon and Schuster, New York.

Dove, M. 1993. A revisionist view of tropical deforestation and development. Environmental Conservation 20: 17-24. 
Ehui, S.K. and T.W. Hertel. 1989. Deforestation and agricultural productivity in the Côte d'Ivoire. American Journal of Agricultural Economics 71(3): 703-711.

Enloe, C. 1989. Bananas, Beaches and Bases: Making Feminist Sense of International Politics. University of California Press, Berkeley.

FAO. 1989. Report on Field Case Studies of Forest Concessions. Ministry of Forestry/FAO Field Document No. 1-5, Jakarta.

Fortmann, L. and J.W. Bruce. (eds.) 1988. Whose Trees? Proprietary Dimensions of Forestry. Westview Press, Boulder, Colorado.

Fulcher, M. 1982. Dayak and transmigration communities in East Kalimantan. Borneo Research Bulletin 14(1): 14-24.

Guha, R. 1993. The malign encounter: The Chipko movement and competing visions of nature. In: T. Banuri and F.A. Marglin (eds.), Who Will Save the Forests?: Knowledge, Power and Environmental Destruction. Zed Books, London. pp. 80-113.

van Haaften, H. 1995. Final report/diary. Prepared for CIFOR's project on Testing Criteria and Indicators for Sustainable Management of Forests, Côte d'Ivoire.

van Haaften, H. and F.J.R. Van de Vijver. 1995. Psychological consequences of environmental degradation: an exploratory study in the Sahel. Internal Paper, Department of Forestry, Wageningen, The Netherlands.

Harris, M. 1968. The Rise of Anthropological Theory: A History of Theories of Culture. Thomas Y. Crowell, New York.

Hladik, C. M., A. Hladik, O. F. Linares, H. Pagezy, A. Semple and M. Hadley. 1993. Tropical Forests, People and Food. The Parthenon Publishing Group, Paris.

Jordan, B. 1991. Technology and social interaction: notes on the achievement of authoritative knowledge in complex settings. Institute for Research on Learning, Palo Alto, California.

Jordan, B. In press. Authoritative knowledge and its construction. In: R. Davis-Floyd and C. Sargent (eds.), Childbirth and Authoritative Knowledge: Crosscultural Perspectives. University of California Press, San Francisco.

Kirk, R. with J. Franklin. 1992. The Olympic Rain Forest: An Ecological Web. University of Washington Press, Seattle.

Lien, C. 1991. Olympic Battleground: The Power Politics of Timber Preservation. Sierra Club, San Francisco.

Mahar, D.J. 1989. Government Policies and Deforestation in Brazil's Amazon Region. World Wildlife Fund and the Conservation Foundation, Washington, D.C.

Maxwell, S. and C. Bart. 1995. Beyond ranking: exploring relative preferences in P/RRA. Notes on Participatory Learning and Action, NO. 22. IIED Sustainable Agriculture Programme, Brighton, UK.

Miracle, M.P. 1970. The smallholder in agricultural policy and planning: Ghana and the Ivory Coast, 1960 to 1966. Journal of Developing Areas 4: 321-332.

Moran, E. 1981. Developing the Amazon. Indiana University Press, Bloomington.

Moran, E. 1990. Private and public colonisation schemes in Amazonia. In: D. Goodman and A. Hall (eds.), The Future of Amazonia Macmillan, London.

Moran, E. 1993. Managing Amazonian variability with indigenous knowledge. In: C.M. Hladik et al. (eds.), Tropical Forests, People and Food. The Parthenon Publishing Group, Paris. pp. 753-766.

Nurse, M. C., C. R. McKay, J. T. Young and C. A. Asanga. 1995. Biodiversity conservation through community forestry, in the montane forests of Cameroon. Rural Development Forestry Network Paper 18d (ODI, Regent's College, Regent's Park, London), Winter 1994-Spring 1995: 14-19.

Peluso, N. 1991. Forest dependence and vulnerability: the role of differential access to forests and trees. Report to the FAO Community Forestry Unit (May).

Peluso, N. 1992. Rich Forests, Poor People: Resource Control and Resistance in Java. University of California Press, Berkeley.

Peluso, N. 1993. The Impact of Social and Environmental Change on Forest Management: A Case Study from West Kalimantan, Indonesia. FAO Community Forestry Case Study Series No. 8, FAO, Rome.

Poffenberger, M. (ed.) 1990. Keepers of the Forest: Land Management Alternatives in Southeast Asia. Kumarian Press, West Hartford, Connecticut.

Posey, D. 1992. Interpreting and applying the "reality" of indigenous concepts: what is necessary to learn from the natives? In: K.H. Redford and C. Padoch (eds.), Conservation of Neotropical Forests: Working from Traditional Resource Use. Columbia University Press, New York. pp. 21-34. 
Posey, D. 1993. The importance of semi-domesticated species in post-contact Amazonia: effects of the Kayapo Indians on the dispersal of flora and fauna. In: C.M. Hladik et al. (eds.), Tropical Forests, People and Food. The Parthenon Publishing Group, Paris. pp. 63-71.

Redford, K.H. and C. Padoch. (eds.) 1992. Conservation of Neotropical Forests: Working from Traditional Resource Use. Columbia University Press, New York.

van Reuler, H., K. N'Goran and M. Wessel. 1994. L'Agriculture. In: E.P Riezebos, A.P. Vooren and J.L. Guillaumet (eds.), Le Parc National de Tai, Côte d'Ivoire. La Fondation Tropenbos Series 8, Wageningen. pp. 133141.

Richards, E. M. 1993. Commercialization of Non-Timber Forest Products in Amazonia, NRI Socio-economics Series 2. Natural Resources Institute, Chatham, UK.

Riezebos, E.P., A.P. Vooren and J.L. Guillaumet. (eds.) 1994. Le Parc National de Tai, Côte d'Ivoire. La Fondation Tropenbos Series 8, Wageningen

Sakuntaladewi, N. and M. Amblani. 1989. Investigation of the Steps Needed to Rehabilitate the Areas of East Kalimantan Seriously Affected by Fire. Deutsche Forstservice GmbH, FR-Report No. 11, Samarinda, East Kalimantan.

Salafsky, N., B.L. Dugelby and J.W. Terborgh. 1993. Can extractive reserves save the rain forest? An ecological and socioeconomic comparison of nontimber forest product extraction systems in Peten, Guatemala, and West Kalimantan, Indonesia. Conservation Biology 7(1): 39-52.

Sayer, J. 1991. Rainforest Buffer Zones: Guidelines for Protected Area Managers. IUCN, Cambridge, UK.

Scott, J.C. 1985. Weapons of the Weak: Everyday Forms of Peasant Resistance: Yale University Press, New Haven.

Seymour, R.S., R.J. Hrubes and D. Hammel. 1995. Certifying sustainable forestry: the evaluator's perspective. Journal of Forestry 93(4): 26-29.

Smith, C.L. and B.S. Steel. 1995. Core-periphery relationships of resource-based communities. Journal of the Community Development Society 26(1): 52-70.

SODEFOR. 1994a. Plan d'Amenagement de la Forêt Classée de la Bossematié (22,200 ha) 1995-2014. Abengourou, Côte d'Ivoire.

SODEFOR. 1994b. Plan d'Amenagement de la Forêt Classée du Haut-Sassandra (102,400 ha) 1995-2014. DaloaVavouia, Côte d'Ivoire.

Vail, D. 1993. The internal conflict: contract logging, chainsaws and clear-cuts in Maine forestry. In: T. Banuri and F.A. Marglin (eds.), Who will Save the Forests?: Knowledge, Power and Environmental Destruction. Zed Books, London. pp.142-189.

Vayda, A.P. and A. Sahur. 1985. Forest clearing and pepper farming by Bugis migrants in East Kalimantan: antecedents and impacts. Indonesia 39: 93-110.

Vayda, A.P., C.J. Pierce Colfer and M. Brotokusumo. 1980. Interactions between people and forests in East Kalimantan. Impact of Science on Society 30(3): 179-190.

Wiersum, K. F. 1986. The effects of intensification of shifting cultivation in Africa on stabilizing land-use and forest conservation. Netherlands Journal of Agricultural Science 34: 485-488.

World Bank. 1991. Policy on indigenous peoples. Operational Directive 4.20 (17 September). 
Table 1. Stakeholder Traits - East Kalimantan, Indonesia (Borneo)

\begin{tabular}{|c|c|c|c|c|c|c|c|}
\hline \multirow{2}{*}{$\begin{array}{l}\text { "STAKE- } \\
\text { HOLDERS" }\end{array}$} & \multicolumn{7}{|c|}{ Dimensions } \\
\hline & Proximity & $\begin{array}{l}\text { Pre-existing } \\
\text { Rights }\end{array}$ & Dependency & $\begin{array}{l}\text { Indigenous } \\
\text { Knowledge }\end{array}$ & $\begin{array}{l}\text { Culture/ } \\
\text { Forest } \\
\text { Integration }\end{array}$ & $\begin{array}{l}\text { Power } \\
\text { Deficit }\end{array}$ & VALUE \\
\hline Dayak & 1 & 1 & 1 & 1 & 1 & 1 & 1.00 \\
\hline Kutai & 1 & 1 & 1 & 1 & 1 & 1 & 1.00 \\
\hline Transmigrant & 1 & var. & 1 & var. & var. & 1 & 1.00 \\
\hline Forest Workers & 1 & 3 & 1 & var. & var. & 1 & 1.50 \\
\hline $\begin{array}{l}\text { Small Scale } \\
\text { Enterpren. }\end{array}$ & 2 & var. & 2 & 2 & 2 & 2 & 2.00 \\
\hline $\begin{array}{l}\text { Company } \\
\text { Officials }\end{array}$ & 2 & 3 & 1 & 3 & 3 & 3 & 2.50 \\
\hline $\begin{array}{l}\text { Forestry } \\
\text { Officials }\end{array}$ & 3 & 3 & 1 & 3 & 3 & 3 & 2.67 \\
\hline $\begin{array}{l}\text { Environ- } \\
\text { mentalists }\end{array}$ & 3 & 3 & 2 & 3 & 2 & 3 & 2.67 \\
\hline $\begin{array}{l}\text { National } \\
\text { Citizens }\end{array}$ & 3 & 3 & 2 & 3 & 3 & var. & 2.80 \\
\hline Consumers & 3 & 3 & 3 & 3 & 3 & var. & 3.00 \\
\hline
\end{tabular}

$1=$ High; 2 = Medium; 3 = Low 
Table 2. Stakeholder Traits - Côte d'Ivoire

\begin{tabular}{|c|c|c|c|c|c|c|c|}
\hline \multirow{2}{*}{$\begin{array}{l}\text { "STAKE- } \\
\text { HOLDERS" }\end{array}$} & \multicolumn{7}{|c|}{ Dimensions } \\
\hline & Proximity & $\begin{array}{l}\text { Pre-existing } \\
\text { Rights }\end{array}$ & Dependency & $\begin{array}{l}\text { Indigenous } \\
\text { Knowledge }\end{array}$ & $\begin{array}{l}\text { Culture/ } \\
\text { Forest } \\
\text { Integration }\end{array}$ & $\begin{array}{l}\text { Power } \\
\text { Deficit }\end{array}$ & VALUE \\
\hline Agni & 1 & 1 & 1 & 1 & 1 & 2 & 1.17 \\
\hline Forest Workers & 1 & var. & 1 & 2 & 2 & 1 & 1.40 \\
\hline Allochtones & 1 & 2 & 1 & 2 & 2 & 1 & 1.50 \\
\hline Allogens & 1 & 3 & 1 & 2 & 2 & 1 & 1.67 \\
\hline Tacherons & 2 & var. & 2 & 2 & var. & 2 & 2.00 \\
\hline $\begin{array}{l}\text { Forestry } \\
\text { Officials }\end{array}$ & 3 & 2 & 1 & 3 & 3 & 3 & 2.50 \\
\hline $\begin{array}{l}\text { [National } \\
\text { Citizens] }\end{array}$ & 3 & 2 & 3 & 3 & 3 & var & 2.60 \\
\hline $\begin{array}{l}\text { Company } \\
\text { Officials }\end{array}$ & 3 & 3 & 1 & 3 & 3 & 3 & 2.67 \\
\hline $\begin{array}{l}\text { [Environ- } \\
\text { mentalists] }\end{array}$ & 3 & 3 & 3 & 3 & 2 & 3 & 2.84 \\
\hline Consumers & 3 & 3 & 3 & 3 & 3 & var. & 3.00 \\
\hline
\end{tabular}

$1=$ High; 2 = Medium; 3 = Low 
Table 3. Stakeholder Traits - Bushler Bay, Washington, USA

\begin{tabular}{|c|c|c|c|c|c|c|c|}
\hline \multirow{2}{*}{$\begin{array}{l}\text { "STAKE- } \\
\text { HOLDERS" }\end{array}$} & \multicolumn{7}{|c|}{ Dimensions } \\
\hline & Proximity & $\begin{array}{l}\text { Pre-existing } \\
\text { Rights }\end{array}$ & Dependency & $\begin{array}{l}\text { Indigenous } \\
\text { Knowledge }\end{array}$ & $\begin{array}{l}\text { Culture/ } \\
\text { Forest } \\
\text { Integration }\end{array}$ & $\begin{array}{l}\text { Power } \\
\text { Deficit }\end{array}$ & VALUE \\
\hline Loggers & 1 & 2 & 2 & 1 & 1 & 1 & 1.30 \\
\hline $\begin{array}{l}\text { Small Scale } \\
\text { Entrepren. }\end{array}$ & 1 & 2 & 2 & 2 & 1 & 2 & 1.70 \\
\hline $\begin{array}{l}\text { Environ- } \\
\text { mentalists }\end{array}$ & 1 & 3 & 2 & 2 & 1 & 2 & 1.80 \\
\hline $\begin{array}{l}\text { Government } \\
\text { Employees }\end{array}$ & 1 & 2 & 2 & 3 & 3 & 3 & 2.30 \\
\hline Politicians & 3 & 3 & 3 & 3 & 3 & 3 & 3.00 \\
\hline $\begin{array}{l}\text { National } \\
\text { Citizens }\end{array}$ & 3 & 3 & var. & 3 & var. & var. & 3.00 \\
\hline Consumers & var. & 3 & 3 & 3 & 3 & var. & 3.00 \\
\hline
\end{tabular}

$1=$ High $; 2=$ Medium; 3 = Low 